\title{
A Case of Glioblastoma Multiforme with Long Term Survival: Can We Predict the Outcome?
}

\author{
Uzun Dönem Să̆kalımlı Bir Glioblastoma Multiforme Olgusu: \\ Sonucu Öngörebilir miyiz?
}

Ashish KUMAR, Chandrashekhar DEOPUJARI, Vikram KARMARKAR

Bombay Hospital Institute of Medical Sciences, Department of Neurosurgery, Mumbai, India

Correspondence address: Ashish KUMAR / E-mail: ashish_med@rediff.com

\begin{abstract}
Glioblastoma Multiforme (GBM) presents a major challenge for a neurosurgeon as the most common primary malignant tumour of the central nervous system. The median life span after the diagnosis still remains between 6 months to 1 year even after gross total excision of the tumour. However, few patients survive long and develop recurrence after a substantial time interval. The exact reason behind the long term survival in GBM cases remains obscure. However, few predictors have been identified of late. Young age, p53 positivity, O6-methylguanine methyltransferase (MGMT) methylation, aggressive surgical resection and a good pre-operative Karnofsky Performance Score (KPS) have been identified with good survival rates in these select cases. Immunohistochemistry forms an integral part of a glioblastoma work up and it must be done in each and every case as it may provide crucial insights regarding prognosis. We report a rare case of glioblastoma multiforme with a long term survival of 20 years. This patient developed a frontal cystic tumour bilaterally in these 20 years and is still leading an active life. The clinical summary, imaging, histopathology, immunohistochemistry along with relevant literature have been discussed.
\end{abstract}

KEYWORDS: Glioblastoma multiforme, Immunohistochemistry, Survival rate, Long term survival

öz

Glioblastoma Multiforme (GBM) merkez sinir sisteminin en sık görülen primer malign tümörü olarak beyin cerrahı için büyük bir zorluk oluşturur. Tanıdan sonra medyan ömür tümörün gross total eksizyonundan sonra bile halen 6 ay ile 1 yıl arasındadır. Ancak, birkaç hasta uzun süre yaşar ve önemli bir zaman geçtikten sonra rekürans görülür. GBM vakalarında uzun dönemli sağkalımın tam nedeni bilinmemektedir. Ancak, son zamanlarda sonucu öngörmeye yardımcı olacak birkaç faktör tanımlanmıştır. Genç yaş, p53 pozitifliği, O6-metilguanin metiltransferaz (MGMT) metilasyonu, agresif cerrahi rezeksiyon ve iyi bir preoperatif Karnofsky Performans Skoru (KPS) seçilmiş vakalarda iyi sağkalım oranlarıyla ilişkili olarak tanımlanmıştır. İmmünohistokimya, glioblastoma incelemesinin entegre bir parçasıdır ve prognoz hakkında çok önemli bulgular verebileceğinden her vakada yapılmalıdır. 20 yı gibi uzun bir süre sağkalan nadir glioblastoma multiforme vakası sunuyoruz. Hastada bu 20 yıl içinde bilateral frontal kistik tümör gelişmiştir ama halen aktif bir yaşam sürdürmektedir. Klinik özet, görüntüleme sonuçları ve histopatoloji ve immünohistokimya, ilgili literatürle birlikte tartışılmışır.

ANAHTAR SÖZCÜKLER: Glioblastoma multiform, İmmünohistokimya, Sağkalım oranı, Uzun dönemli sağkalım

\section{INTRODUCTION}

Glioblastoma Multiforme (GBM) is the most common primary malignant tumour of brain. The median survival after diagnosis is around 1 year. Approximately $3-5 \%$ of cases can have more than 3 years survival and hence are termed as long term survivors. Efforts have been made to identify the etiology behind these few rare cases and important prognostic factors have been identified on immunohistochemistry. Thus, it becomes crucial on the part of surgeons to evaluate each case for possible good prognostic factors based on the immunohistochemistry. We report the first case of a glioblastoma multiforme from India with a survival of more than 20 years. We will discuss the case history, imaging and evaluate its immunohistochemical findings.

\section{CASE REPORT}

This patient first developed symptoms at the age of 16 years when he developed a generalized seizure. The Computed Tomography (CT) revealed a right frontal space occupying lesion (Figure 1) and he was treated symptomatically with anticonvulsants. He had convulsions again after 3 months and underwent surgical excision this time. The histopathology was diagnostic of glioblastoma multiforme (Figure 2). He received 50 Gray (Gy) radiotherapy and PCV regimen chemotherapy (procarbazine, carmustine and vincristine). Follow up CT after 2 years was normal. He remained asymptomatic for further 13 years, when he had a third episode of seizure. Magnetic Resonance Imaging (MRI) showed a left frontal solid-cystic lesion with irregular contrast enhancement (Figure 3). He underwent second surgery and this time also, the diagnosis was GBM and he received 60 Gy radiotherapy following 


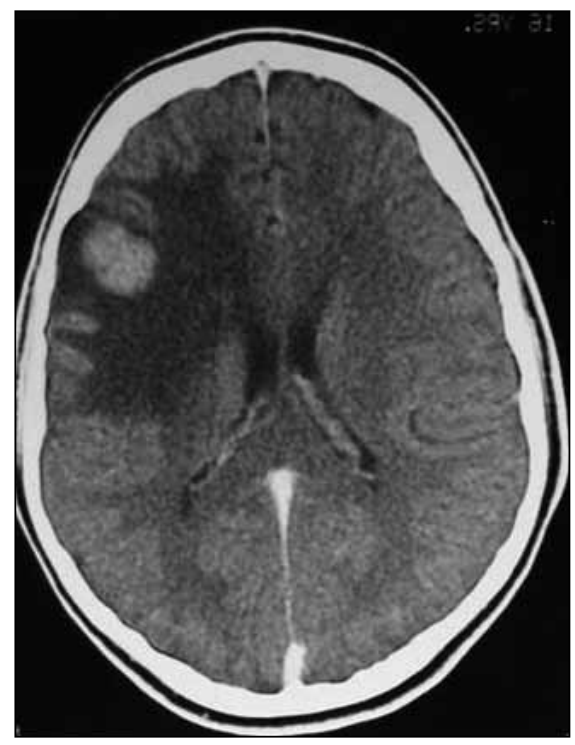

Figure 1: Right frontal enhancing tumour on CT scan.

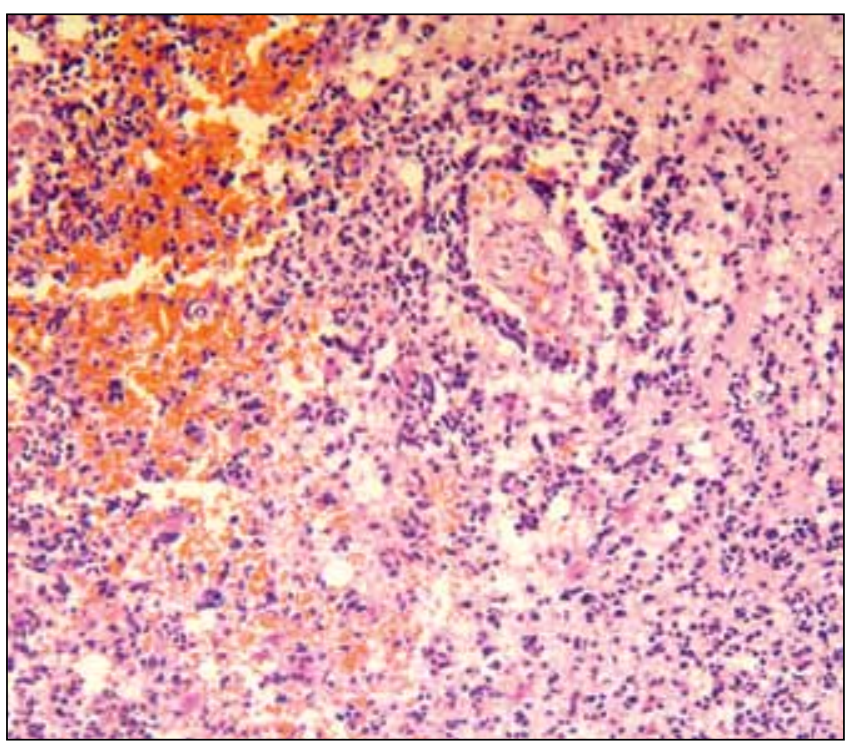

Figure 2: Histopathology suggestive of GBM with increased cellularity after the first surgery.

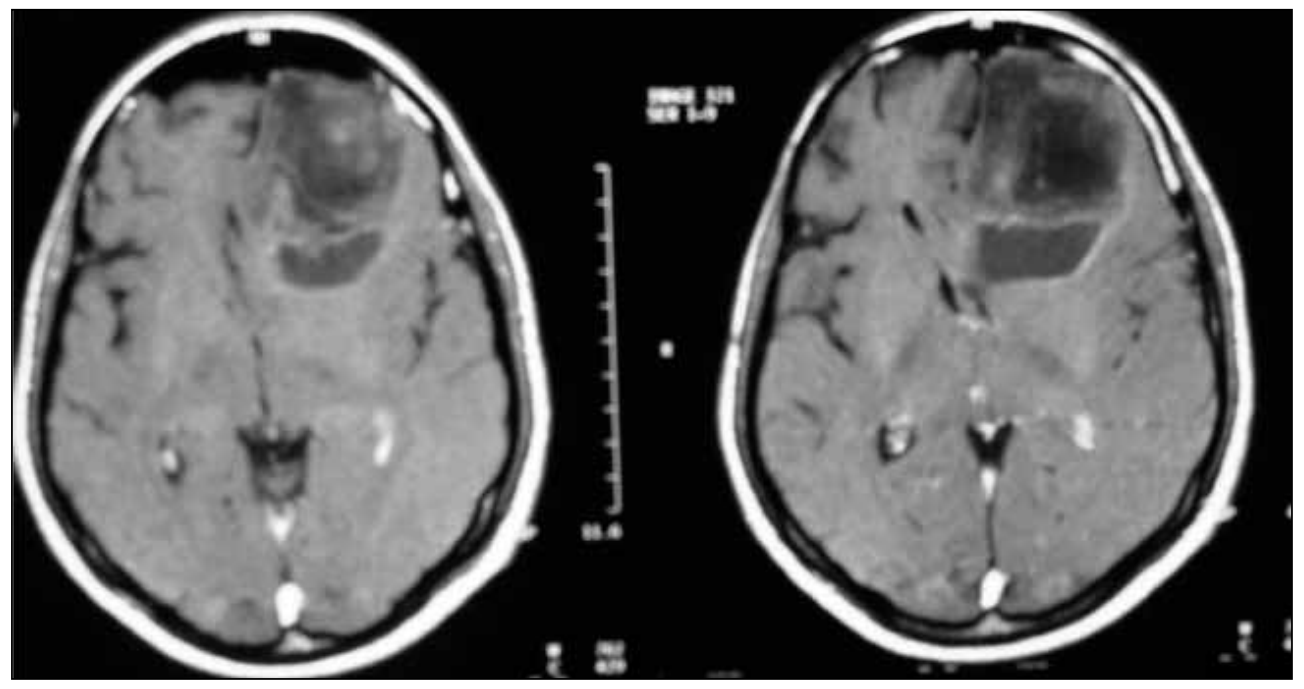

Figure 3: MRI showing left frontal solid cystic lesion. surgery. He was alright and follow-up MRI after 2 years and a positron emission tomography scan after 4 years did not reveal any recurrence (no 18-Fluoro deoxy glucose uptake). Recently, after 20 years of his first presentation he developed a fourth episode of seizure and the contrast CT showed a left frontal cystic recurrence (Figure 4). He underwent a left frontal craniotomy and re-surgery for the left frontal tumour. Histopathology showed features of micro-vascular proliferation and necrosis with increased mitotic figures which were consistent with glioblastoma multiforme (Figure 5). Immunohistochemistry was done and it showed high Ki67 index (Figure 6) and positivity for p53 mutation (Figure 7) and EGFR (Epidermal Growth Factor Receptor; Figure 8). $\mathrm{O}^{6}$ methylguanine methyltransferase (MGMT) methylation status was positive. Thus, this 36-year-old patient with a high grade glioma that affected both frontal lobes consecutively has survived for 20 years and is leading an active life (Karnofsky Performance Score (KPS): 90-100)

\section{DISCUSSION}

Glioblastoma multiforme (GBM) is the leading malignant primary tumour in adults with frequent involvement of the middle age group. There have been case reports in the literature quoting long term survival (>3 years) of patients. However, it is rare for a patient to live for 20 years after the first histological diagnosis of GBM has been made. Various prognostic factors have been implicated to affect the long term outcome in glioblastoma multiforme patients. These include younger age, female sex, aggressive surgical resection, oligodendroglial component, giant cell GBM, low proliferation index, high p53 and low epidermal growth factor receptor (EGFR) positivity (1). There have been many isolated case reports of longer survival but only a few patients have survived as long as 20 years. Sperduto et al. have reported a similar case of GBM with a 20 year survival with $\mathrm{p} 53$ and PTEN positivity with methylated MGMT and negative EGFR 


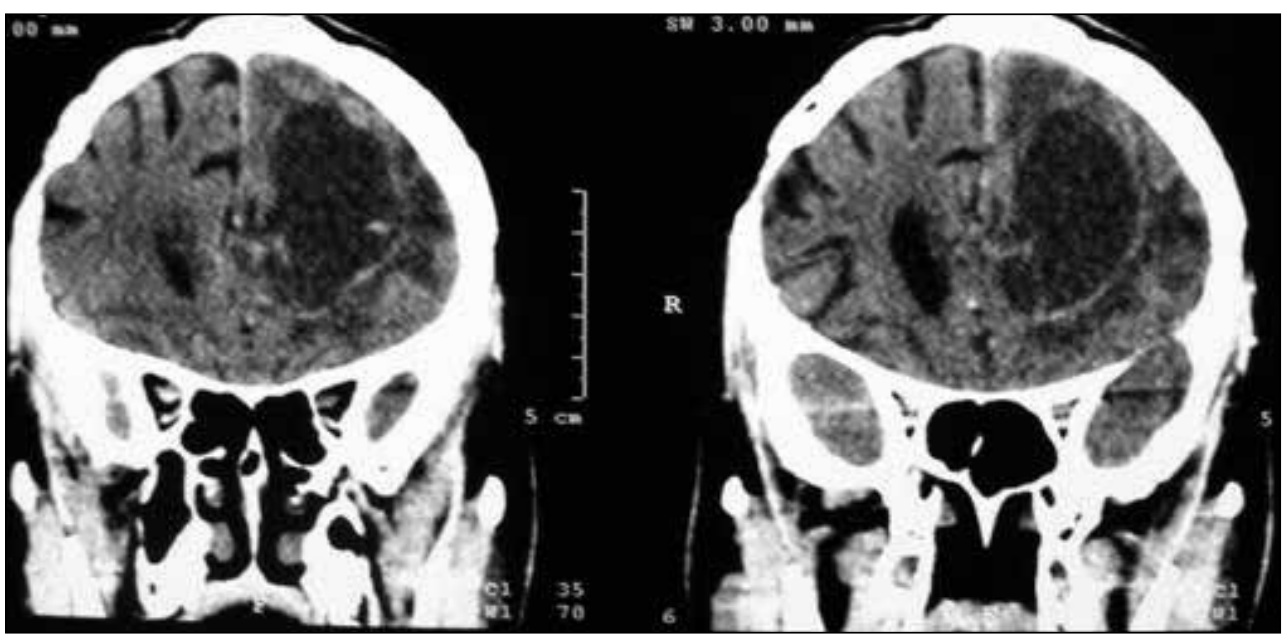

Figure 4: Left frontal mainly cystic recurrence.

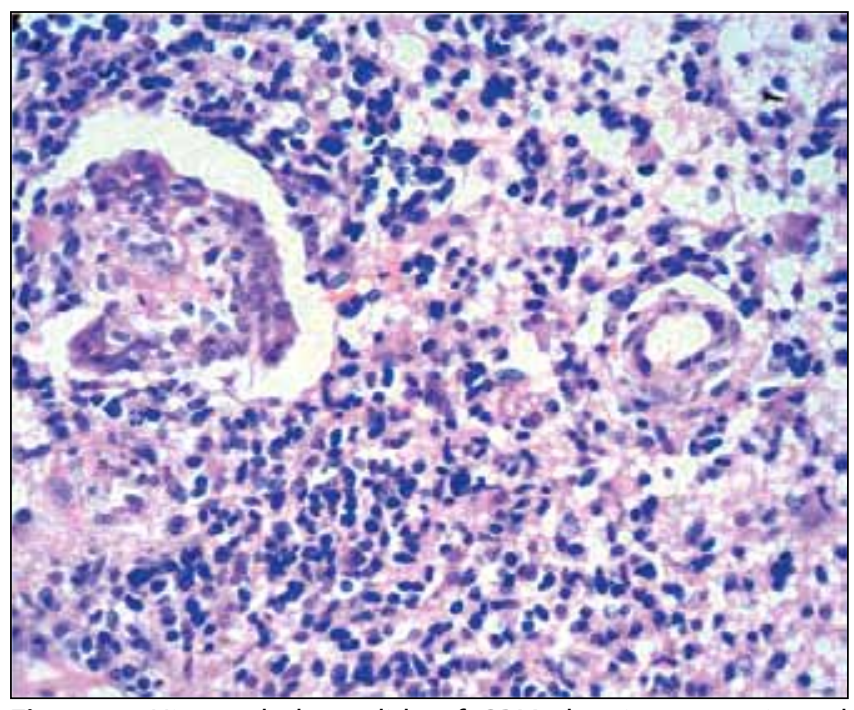

Figure 5: Histopathology slide of GBM showing necrosis and increased mitotic figures.

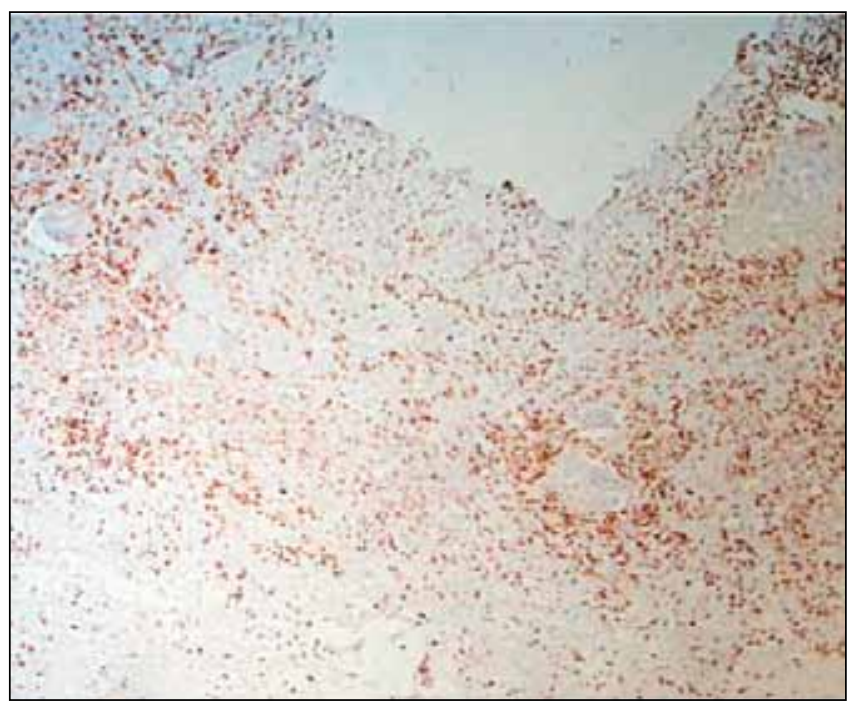

Figure 7: Immunostaining showing high p53 mutation positivity.

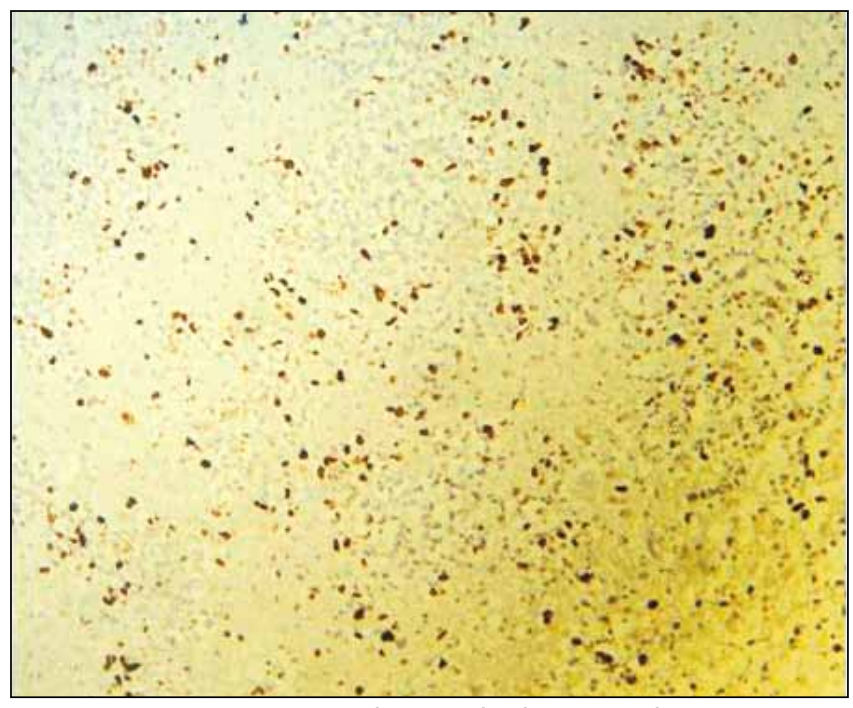

Figure 6: Immunostaining showing high Ki-67 index.

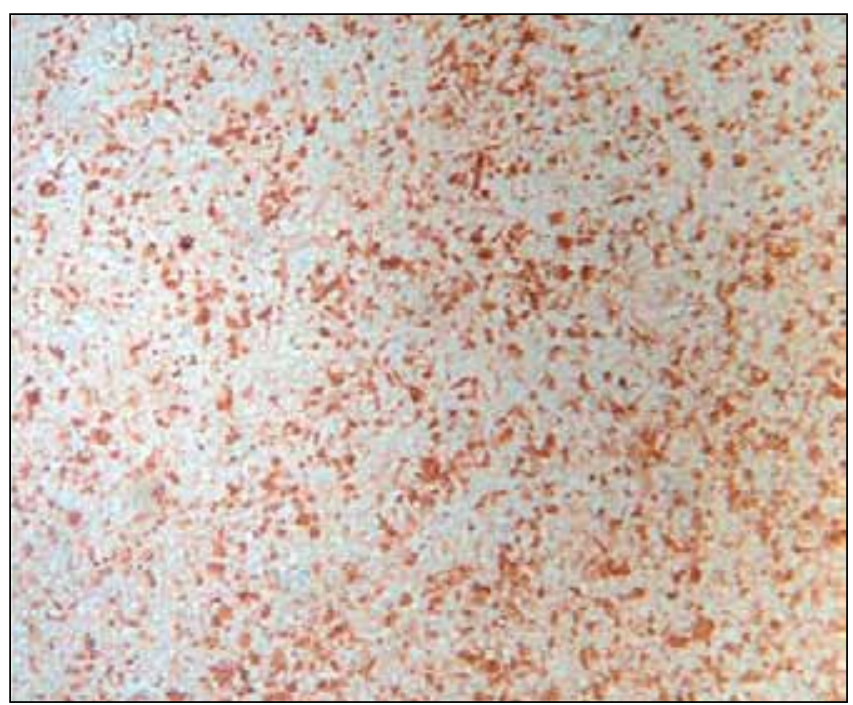

Figure 8: Immunostaining showing rich EGFR status. 


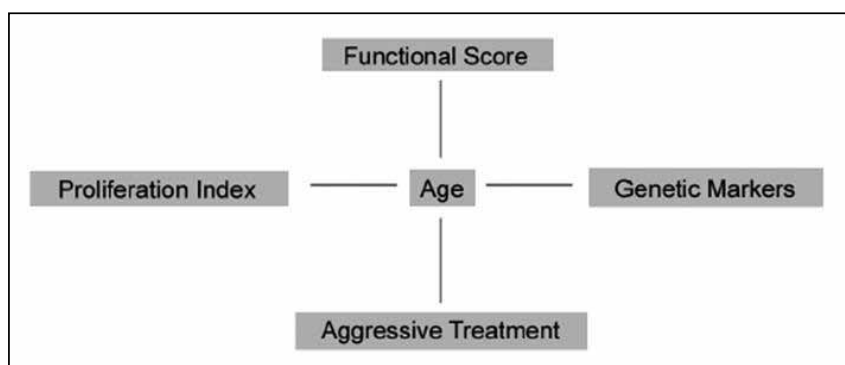

Figure 9: Interaction of various prognostic factors (submitted with permission of Dr Walid).

status (4). Our patient had positive p53 mutation and EGFR over-expression with high Ki67 index. EGFR positivity has an unclear role in determining the prognosis of such patients. Some reports have quoted poor prognosis, some were not able to define its prognostic significance and a few reports have even mentioned about its positive impact on survival. In the largest series of all times, Krex et al. (2) have analyzed 55 of patients of GBM with longer survival of more than 3 years and have found MGMT methylated in $74 \%$ cases. $1 \mathrm{p} 19 \mathrm{q}$ deletion has also been associated with long term survival in glioblastoma patients. However, like EGFR, there has been conflicting reports regarding this. Krex et al. (2) did not find $1 \mathrm{p} \mathrm{19q}$ deletion as an indicator for good prognosis (as in oligodendroglioma) and none of their cases had this deletion. They also assessed socioeconomic, environmental and occupational factors as predisposing factors for longer survival and did not find any correlation with survival rates. The other crucial factor has been the performance status of the patient (Karnofsky performance score, KPS). Patients with a KPS of more than 90 achieve much better outcome than those with the lower scores. In our patient, young age, MGMT methylation status, good performance status and positive p53 mutation goes in line with the available data. The high Ki-67 index in our case, although an adverse factor, proves the diagnosis of glioblastoma and rules out any other tumour with some component of GBM in it. The role of surgery is of paramount importance, where an aggressive resection of the tumour especially in young patients can have impact on the survival rates [Sanai and Berger (3)]. All the current prognosticators in longer surviving patients are interrelated with each other (Figure 9) and this interaction only determines the overall outcome of a patient with GBM (5). The cystic nature of the tumour during the last two recurrences may also point towards a possible favourable prognostic factor, although no such previous data is available in the literature regarding the same. The location of the tumour in a relatively non-eloquent region also helped in maintaining good performance status post-operatively.

\section{CONCLUSIONS}

Long survival in a case of glioblastoma is rare. Young age, low proliferation index (although not in this case), involvement of a non eloquent region, good performance status with favourable immunohistochemistry signify good prognosis and may suggest longer survival rates. However, the cystic nature of tumour as a prognostic factor may require further validation. Immunohistochemistry provides a means to predict outcome in GBM to some extent and therefore, should be done in each and every patient to prognosticate and to find insights to the molecular biology of the tumour.

\section{REFERENCES}

1. Deb P, Sharma MC, Mahapatra AK, Agarwal D, Sarkar C: Glioblastoma multiforme with long term survival. Neurol India 53: 329-332, 2005

2. Krex D, Klink B, Hartmann C, von Deimling A, Pietsch T, Simon M, Sabel M, Steinbach JP, Heese O, Reifenberger G, Weller M, Schackert G: German Glioma Network: Long-term survival with glioblastoma multiforme. Brain 130:2596-2606, 2007

3. Sanai N, Berger MS: Glioma extent of resection and its impact on patient outcome. Neurosurgery 62:753-764, 2008

4. Sperduto CM, Chakravarti A, Aldape K, Burger P, Papermaster GB, Sperduto P: Twenty-year survival in Glioblastoma: A Case Report and molecular profile. Int J Radiat Oncol Biol Phys 75:1162-1165, 2009

5. Walid MS: Prognostic factors for long term survival after Glioblastoma. Perm J 12:45-48, 2008 